\title{
Friedmanniella antarctica gen. nov., sp. nov., an LL-Diaminopimelic Acid-Containing Actinomycete from Antarctic Sandstone
}

\author{
PETER SCHUMANN,${ }^{1 *}$ HELMUT PRAUSER,${ }^{1}$ FREDERICK A. RAINEY ${ }^{2}$ ERKO STACKEBRANDT, ${ }^{2}$ \\ AND PETER HIRSCH ${ }^{3}$ \\ DSMZ-German Collection of Microorganisms and Cell Cultures GmbH, D-07745 Jena, ${ }^{1}$ DSMZ-German Collection of \\ Microorganisms and Cell Cultures GmbH, D-38124 Braunschweig, ${ }^{2}$ and Institute of General Microbiology of the \\ University of Kiel, D-24118 Kiel, ${ }^{3}$ Germany
}

\begin{abstract}
A gram-positive, aerobic, slowly growing actinomycete was isolated from antarctic sandstone. Packets of spherical cells of this organism form clusters. The diagnostic diamino acid of the peptidoglycan is LL-diaminopimelic acid with glycine in position 1 of the peptide subunit. The major menaquinone is $\mathrm{MK}-9\left(\mathrm{H}_{4}\right)$, and the main cellular fatty acids are 12- and 13-methyltetradecanoic acids. Only a few organic compounds are metabolized. The DNA base composition is $73 \mathrm{~mol} \% \mathrm{G}+\mathrm{C}$. A $16 \mathrm{~S}$ ribosomal DNA sequence comparison showed that this isolate is a phylogenetic neighbor of the propionibacteria and related taxa. Its closest relative is Microlunatus phosphovorus. Morphological, physiological, and genotypic characteristics support the description of a new genus and new species, Friedmanniella antarctica gen. nov., sp. nov. The type strain is strain AA-1042 (= DSM 11053).
\end{abstract}

Actinomycete genera which contain LL-diaminopimelic acid $\left(\mathrm{LL}-\mathrm{A}_{2} \mathrm{pm}\right)$ in their peptidoglycan fall in five phylogenetic lineages, as revealed by $16 \mathrm{~S}$ ribosomal DNA (rDNA) sequence analyses. These are (i) the streptomycetes (39), (ii) the genus Terrabacter (5), (iii) the genus Sporichthya (30), (iv) the genera Nocardioides and Aeromicrobium (4, 5, 8, 21, 43), and (v) the genera Propioniferax (49), Luteococcus (42), and Microlunatus (24). These genera are distinguished from each other and from other actinomycete genera mainly by chemotaxonomic characteristics and by their 16S rDNA sequences. From antarctic sandstone a single $\mathrm{LL}-\mathrm{A}_{2} \mathrm{pm}$-containing strain was isolated, and its 16S rDNA was analyzed. On the basis of morphological, physiological, and 16S rDNA analyses, we concluded that this strain, strain AA-1042 ${ }^{\mathrm{T}}$ ( $\mathrm{T}=$ type strain), belongs to a new genus and species, for which the name Friedmanniella antarctica is proposed.

\section{MATERIALS AND METHODS}

Bacterial strains. Strain AA-1042 ${ }^{\mathrm{T}}$ was isolated from a sandstone sample containing a cryptoendolithic microbial community collected by one of us (P.H.) at $1,600 \mathrm{~m}$ above ocean level from Linnaeus Terrace, McMurdo Dry Valleys, Asgard Range, Transantarctic Mountains, Antarctica (15). The sandstone boulder was flat, had an area of approximately $2 \mathrm{~m}^{2}$, and had at the sampling side (east side) a $\mathrm{pH}$ of 4.8 . The stone was quite brittle, and some loosened material was directly sprinkled onto the surfaces of PYGV (41) $(\mathrm{pH} 6.9)$ agar plates. The plates were incubated for 5 months at $9^{\circ} \mathrm{C}$ in dim light. Individual colonies around sand grains were picked and streaked onto the same medium for purification. Resulting single and pure colonies were subcultured after 5 months on PYGV agar slants at 4 to $6^{\circ} \mathrm{C}$. Strain AA- $1042^{\mathrm{T}}$ has been deposited in the IFAM Culture Collection (Institut für Allgemeine Mikrobiologie, Kiel, Germany). The strains used for comparison were the following: Aeromicrobium erythreum NRRL B-3381 $1^{\mathrm{T}}$ (= DSM 8599 $)$, Aeromicrobium fastidiosum NCIB $12713^{\mathrm{T}}$ (= DSM $\left.10552^{\mathrm{T}}\right)$, Intrasporangium calvum $7 \mathrm{KIP}^{\mathrm{T}}\left(=\mathrm{DSM} 43043^{\mathrm{T}}\right)$, Luteococcus japonicus IFO $12422^{\mathrm{T}}$ (= DSM $10546^{\mathrm{T}}$ ), Microlunatus phosphovorus JCM $9379^{\mathrm{T}}(=$ DSM $\left.10555^{\mathrm{T}}\right)$, Nocardioides albus IMET $7807^{\mathrm{T}}\left(=\mathrm{DSM} 43109^{\mathrm{T}}\right)$, Nocardioides simplex NCIB $8929^{\mathrm{T}}\left(=\right.$ DSM $\left.20130^{\mathrm{T}}\right)$, Nocardioides jensenii NCIB $9770^{\mathrm{T}}(=$ DSM $\left.20641^{\mathrm{T}}\right)$, Nocardioides plantarum NCIMB $12834^{\mathrm{T}}\left(=\mathrm{DSM} 11054^{\mathrm{T}}\right)$, Propioniferax innocua NCTC $11082^{\mathrm{T}}$ (= DSM $8251^{\mathrm{T}}$ ), Sporichthya polymorpha

* Corresponding author. Mailing address: DSMZ-Deutsche Sammlung von Mikroorganismen und Zellkulturen GmbH, Aussenstelle Jena, Beutenbergstrasse 11, D-07745 Jena, Germany. Phone: 49 (0)3641 65 8522. Fax: 49 (0)3641 65 8527. E-mail: Pschuman@leutra imb-jena.de.
IMET $7840^{\mathrm{T}}\left(=\right.$ DSM $\left.46113^{\mathrm{T}}\right)$, Streptomyces albus ATCC $3004^{\mathrm{T}}(=\mathrm{DSM}$ $40313^{\mathrm{T}}$ ), and Terrabacter tumescens NCIB $8914^{\mathrm{T}}$ (= DSM $20308^{\mathrm{T}}$ ).

Media. The following media were used in the liquid state or in the semisolid state (prepared by adding $1.5 \%$ [wt/vol] Kobe 1 agar [Serva]): (i) PYGV medium (41); (ii) R medium (48); (iii) modified organic medium 79 (29) containing (per liter) $10 \mathrm{~g}$ of dextrose, $10 \mathrm{~g}$ of Bacto Peptone (Difco), $2 \mathrm{~g}$ of Casamino Acids (Difco), $2 \mathrm{~g}$ of yeast extract (Serva) and $6 \mathrm{~g}$ of $\mathrm{NaCl}$ (pH 7.5); (iv) TSB medium (Difco); (v) enriched nutrient agar (Serva) and enriched nutrient broth (Serva) (pH 7.2).

Cultural conditions. The biomass used for all chemotaxonomic studies of strain $\mathrm{AA}-1042^{\mathrm{T}}$ was produced on R-agar slant cultures at $22^{\circ} \mathrm{C}$ and was harvested after 2 to 3 weeks. Sporichthya polymorpha was cultivated on nutrient agar at $28^{\circ} \mathrm{C}$ for 3 weeks. The other organisms were cultivated at $28^{\circ} \mathrm{C}$ for between 24 and $48 \mathrm{~h}$ in $100-\mathrm{ml}$ flasks containing $20 \mathrm{ml}$ of $\mathrm{R}$ medium by using a horizontal shaker at $220 \mathrm{rpm}$. For menaquinone studies organic medium 79 was used. The cell mass used for analyses of cell walls, mycolic acids, and phospholipids and for DNA extraction was obtained in R medium. Fatty acid analyses were performed with cells grown in TSB medium.

The following temperatures were used to study growth, morphology, and pigmentation: $6,9,18,22,25,28$, and $37^{\circ} \mathrm{C}$. The source of light for strain $\mathrm{AA}-1042^{\mathrm{T}}$ was daylight near a window without direct exposure to sun.

Staining procedures. Gram staining and acid-fast staining were done as described previously (18)

Morphological studies. Cell morphology and aggregate morphology were determined by phase-contrast microscopy (oil immersion objective; magnification, $\times 100$ ) of material obtained from surface growth on agar plates, as well as by direct phase-contrast observation of growing cultures on 2-mm agar layers by using ring cultures $50 \mathrm{~mm}$ in diameter and plastic film to reduce evaporation.

Physiological and biochemical characterization. All physiological tests were performed at $22^{\circ} \mathrm{C}$. Inoculum was taken from R-agar slant or plate cultures Spreading and dispersing of the inoculum were restricted by its consistency. Cultures were examined after $5,8,14$, and 21 days of incubation.

The relationship to oxygen was studied with agar stab cultures and, in parallel slant cultures covered with paraffin oil. Oxidase activity was checked by examining oxidation of $N, N, N^{\prime}, N^{\prime}$-tetramethyl-p-phenylenediamine dihydrochloride (38). Acidification of carbohydrates was verified by a color change from blue to yellow in a medium containing $0.5 \%$ (wt/vol) Bacto Tryptone (Difco), $0.4 \%$ (wt/vol) Casamino Acids (Difco), $0.07 \%$ (wt/vol) $\left(\mathrm{NH}_{4}\right)_{2} \mathrm{HPO}_{4}, 0.5 \%$ (wt/vol) $\mathrm{NaCl}, 0.003 \%(\mathrm{wt} / \mathrm{vol})$ bromcresol purple, and the substrates at a final concentration of $1 \%(\mathrm{wt} / \mathrm{vol})$. Utilization of organic acids as carbon sources (13) and decomposition of adenine, xanthine, hypoxanthine, and DL-tyrosine were determined as described previously (12). Catalase production was shown by the production of bubbles after a suspension of the organism was mixed with a drop of a $3 \%$ hydrogen peroxide solution on a slide. Urease activity, nitrate reduction, esculin hydrolysis, and hydrolysis of Tween 80 were studied by using previously described methods (18). Decomposition of the emulsion of UV-sterilized cinefilm stripes incubated in phosphate buffer was used to verify gelatin hydrolysis Clear zones in streak-inoculated agar (a mixture of $6 \mathrm{ml}$ of liquefied aqua dest. agar and $2 \mathrm{ml}$ of steamed skim milk) indicated positive casein hydrolysis reactions. DNA hydrolysis was indicated by clear zones in spot-inoculated plate containing Bacto DNase test agar (Difco). Decomposition of hippurate was 
determined as described previously (9). Hydrolysis of starch was shown by the occurrence of colorless zones around colonies grown on inorganic salts-starch agar (37) after the surface was flooded with Lugol's solution containing $0.1 \%$ (wt/vol) iodine and $0.2 \%(\mathrm{wt} / \mathrm{vol})$ potassium iodide. $\mathrm{H}_{2} \mathrm{~S}$ production was determined as described previously (27). $\mathrm{NaCl}$ tolerance was checked on $\mathrm{R}$ agar containing $\mathrm{NaCl}$ at final concentrations of 2,4 , and $10 \%(\mathrm{wt} / \mathrm{vol}$ ).

Color determination. Colors of agar cultures were determined by using a color code (26) as applied in the International Streptomyces Project (37)

Cell wall analysis. Purified cell wall preparations were obtained by previously described methods (35). Amino acids and peptides of cell wall hydrolysates were analyzed by two-dimensional ascending thin-layer chromatography on cellulose plates by using the solvent systems described previously (35). Cell wall sugars were determined as alditol acetates (32) by gas chromatography (GC) and gas chromatography-mass spectrometry (GC-MS). Molar ratios of amino acids were determined by GC and GC-MS of $N$-heptafluorobutyryl amino acid isobutyl esters (19). The instruments used for GC and GC-MS have been described previously (14). The glycolate content of bacterial cells was determined by the colorimetric method described by Uchida and Aida (44).

Lipid analysis. Cellular fatty acid methyl esters were separated by GC and GC-MS as described previously (14). They were identified by comparison with the Bacterial Acid Methyl Esters CP Mix (catalog no. 1114; Matreya Inc., Pleasant $\mathrm{Gap}, \mathrm{Pa}$.) and with fatty acid methyl ester extracts from Dermacoccus nishinomiyaensis DSM $20448^{\mathrm{T}}$ containing unsaturated iso and anteiso methylbranched acids (40). 2-Hydroxyhexadecanoic acid methyl ester was identified on the basis of its characteristic fragment ion having a mass of 227 by GC-MS Menaquinones were extracted (7) and analyzed by high-performance liquid chromatography as described previously (14). Polar lipids extracted as described by Minnikin et al. (23) were identified by two-dimensional thin-layer chromatography and spraying with specific reagents (6). The absence of mycolic acids was demonstrated as described previously (22).

Analysis of DNA base composition. DNA was isolated and its $\mathrm{G}+\mathrm{C}$ content was determined by high-performance liquid chromatography as described previously (14).

$16 S$ rDNA sequence determination and analysis. Genomic DNAs were extracted from the strains investigated in this study and were used for PCRmediated amplification of $16 \mathrm{~S}$ rDNA (31). The purified PCR products were directly sequenced by using previously described protocols (31), and the sequence reaction mixtures were electrophoresed with a model $373 \mathrm{~A}$ automatic DNA sequencer (Applied Biosystems, Foster City, Calif.)

The 16S rDNA sequences were manually aligned with the sequences of members of the order Actinomycetales by using the ae 2 editor (20). Evolutionary distances were calculated as described previously (16). Phylogenetic dendrograms were reconstructed by using treeing algorithms contained in the PHYLIP package (11). Bootstrap analyses were used to evaluate the tree topologies of the neighbor-joining data by performing 1,000 resamplings (10)

Nucleotide sequence accession numbers. The $16 \mathrm{~S}$ rDNA sequences determined in this study have been deposited in the EMBL database under the following accession numbers: strain AA-1042 ${ }^{\mathrm{T}}\left(=\mathrm{DSM} 11053^{\mathrm{T}}\right), \mathrm{Z} 78206$;

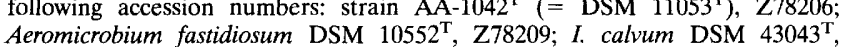
Z78214; L. japonicus DSM $10546^{\mathrm{T}}$, Z78208; Microlunatus phosphovonus DSM $10555^{\mathrm{T}}, \mathrm{Z} 78207$; Nocardioides albus DSM $43109^{\mathrm{T}}, \mathrm{Z78213}$; Nocardioides jensenii

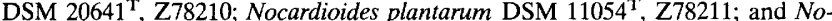
cardioides simplex DSM $20130^{\mathrm{T}}, \mathrm{Z} 78212$. The accession numbers of the sequences of the reference strains used in the phylogenetic analyses are as follows: Actinoplanes philippinensis DSM 43019 ${ }^{\mathrm{T}}$, X93187; Aeromicrobium enthreum NRRL B-3381 ${ }^{\mathrm{T}}$, M37200; Arthrobacter globiformis DSM 20124 ${ }^{\mathrm{T}}$, M23411; Atopobium minutum ATCC $33267^{\mathrm{T}}$, M59059; Microbacterium lacticum DSM $20427^{\mathrm{T}}$, X77441; Nocardia asteroides DSM 43757 $7^{\mathrm{T}}$, X80606; Propionibacterium acnes DSM $1897^{\mathrm{T}}$, X53218; Propionibacterium freudenreichii DSM $20271^{\mathrm{T}}, \mathrm{X} 53217$; Propioniferax innocua DSM 8251 ${ }^{\mathrm{T}}$, S93388; T. tumescens DSM 20308 ${ }^{\mathrm{T}}, \mathrm{X} 83812$; Saccharothrix australiensis ATCC $31497^{\mathrm{T}}$, X5192; Sporichthya polymorpha DSM $46113^{\mathrm{T}}, \mathrm{X} 72377$; and Streptomyces albidoflavus DSM 40455 ${ }^{\mathrm{T}}, \mathrm{Z} 76676$

\section{RESULTS}

Cultural characteristics. $\mathrm{R}$ agar, $22^{\circ} \mathrm{C}$, and diffuse daylight were found to be optimal for growth of strain AA-1042 ${ }^{\mathrm{T}}$ as measured by the diameter of the colonies. The following results were obtained under these conditions. Visible growth appeared 4 days after $\mathrm{R}$ agar was inoculated from 2-week-old cultures on this medium. The colonies reached the maximum size within 2 to 3 weeks. The raised colonies (diameter, 0.5 to $2.2 \mathrm{~mm}$ ) had dull and crumbly surfaces. The edges and surfaces were irregular and depended on the internal structure of the colonies. The color was bright orange (color code [37], Oc $2 \mathrm{r}-\mathrm{O})$ but was less intense when the organism was grown in the dark. In aging cultures the color changed from orange to yellow (color code, Co 3a-Cr) and finally to faint yellow; this was accompanied by a decline in viability and even a loss of viability. Growth was slower and there was less growth on PYGV agar than on $\mathrm{R}$ agar; the orange color was less intense (color code, Oc 3a), and the colony surface became smooth and shiny.

The temperature range for growth on $\mathrm{R}$ agar was 18 to $25^{\circ} \mathrm{C}$, and the optimum temperature was $22^{\circ} \mathrm{C}$. Growth was slow and poor at $9^{\circ} \mathrm{C}$, and growth did not occur at 6,28 , or $37^{\circ} \mathrm{C}$. Addition of $2 \%$ (wt/vol) $\mathrm{NaCl}$ to $\mathrm{R}$ agar resulted in restricted growth, while no growth occurred in the presence of $4 \%$ (wt/ vol) $\mathrm{NaCl}$. The optimal $\mathrm{pH}$ was 6.0 to 7.2 . At $\mathrm{pH} 8.1$ growth was very poor, and no growth occurred at $\mathrm{pH} 5.1$ and 8.7 .

Growth was slow and very poor in submerged cultures. Growth could be improved by aeration. Shaken cultures turned faintly turbid, and the material sedimented rapidly. There was no growth in stab cultures and on agar slant cultures covered with paraffin oil. There was less growth and cluster formation on PYGV agar than on $\mathrm{R}$ agar, and the color was yellow to orange.

Maintenance. Serial transfers at 2-week intervals on R-agar slant cultures at $22^{\circ} \mathrm{C}$ under diffuse daylight kept the culture viable. Strain AA- $1042^{\mathrm{T}}$ was lyophilized in PYGV medium and was subcultured successfully after 27 months of storage at $4^{\circ} \mathrm{C}$. Maintenance in the vapor phase of liquid nitrogen resulted in good viability when the organism was recultivated after 33 months. Permanent cultures in glycerol were not prepared since the two other methods proved to be successful.

Morphological characteristics. On PYGV medium single cells were spherical or nearly spherical and ranged from 1.2 to $1.5 \mu \mathrm{m}$ in diameter. Occasionally larger cells that were 2.0 to $2.2 \mu \mathrm{m}$ in diameter were observed. On R agar the cells varied from 0.5 to $2.2 \mu \mathrm{m}$ in diameter. Generally, the cells occurred in packets (Fig. 1A and B) which resulted from cell division in three perpendicular planes. The packets adhered to one another, forming clusters (Fig. 1A and B). The clusters were more regular on PYGV medium (Fig. 1A) than on R medium (Fig. 1B). On R agar, dividing cells had an ellipsoidal appearance (Fig. 1C). Motile cells and formation of spores were never observed.

Staining reactions. Strain AA- $1042^{\mathrm{T}}$ stained gram positive and no lysis was observed following treatment with $3 \%$ (wt/vol) $\mathrm{KOH}$. The cells were not acid fast.

Physiological characteristics. Strain AA $-1042^{\mathrm{T}}$ grew strictly aerobically. The oxidase test was negative. Microlunatus phosphovorus, which was described as weakly oxidase positive (24), was found in this study to be distinctly oxidase positive. Catalase and urease were produced. Nitrate was not reduced to nitrite. Acid was produced from D-ribose, was produced weakly from L-arabinose, and was produced very weakly from D-xylose. No acid was produced from L-rhamnose, D-glucose, D-fructose, D-mannose, D-galactose, maltose, lactose, sucrose, D-cellobiose, D-trehalose, D-raffinose, glycerol, D-mannitol, and myo-inositol. Starch and esculin were hydrolyzed, while Tween 80 and DNA were only weakly hydrolyzed. Casein and gelatin were not hydrolyzed. Sodium formate was utilized as a carbon source. Sodium acetate, sodium aconitate, sodium benzoate, sodium citrate, disodium succinate, and potassium hydrogen tartrate were not utilized. Hypoxanthine, xanthine, adenine, DL-tyrosine, and sodium hippurate were not decomposed. $\mathrm{H}_{2} \mathrm{~S}$ was produced.

Chemotaxonomic characteristics. The fatty acid profile of strain AA-1042 ${ }^{\mathrm{T}}$ (Table 1) is characterized by the predominance of anteiso- $\mathrm{C}_{15: 0}$ and iso- $\mathrm{C}_{15: 0}$ and the occurrence of iso-branched tetra- and hexadecanoic acids, iso-hexadecenoic acid, and octadecadienoic acid. Since the results of fatty acid analyses vary to some degree between laboratories and the methods used differ to some extent, the fatty acid profiles of 

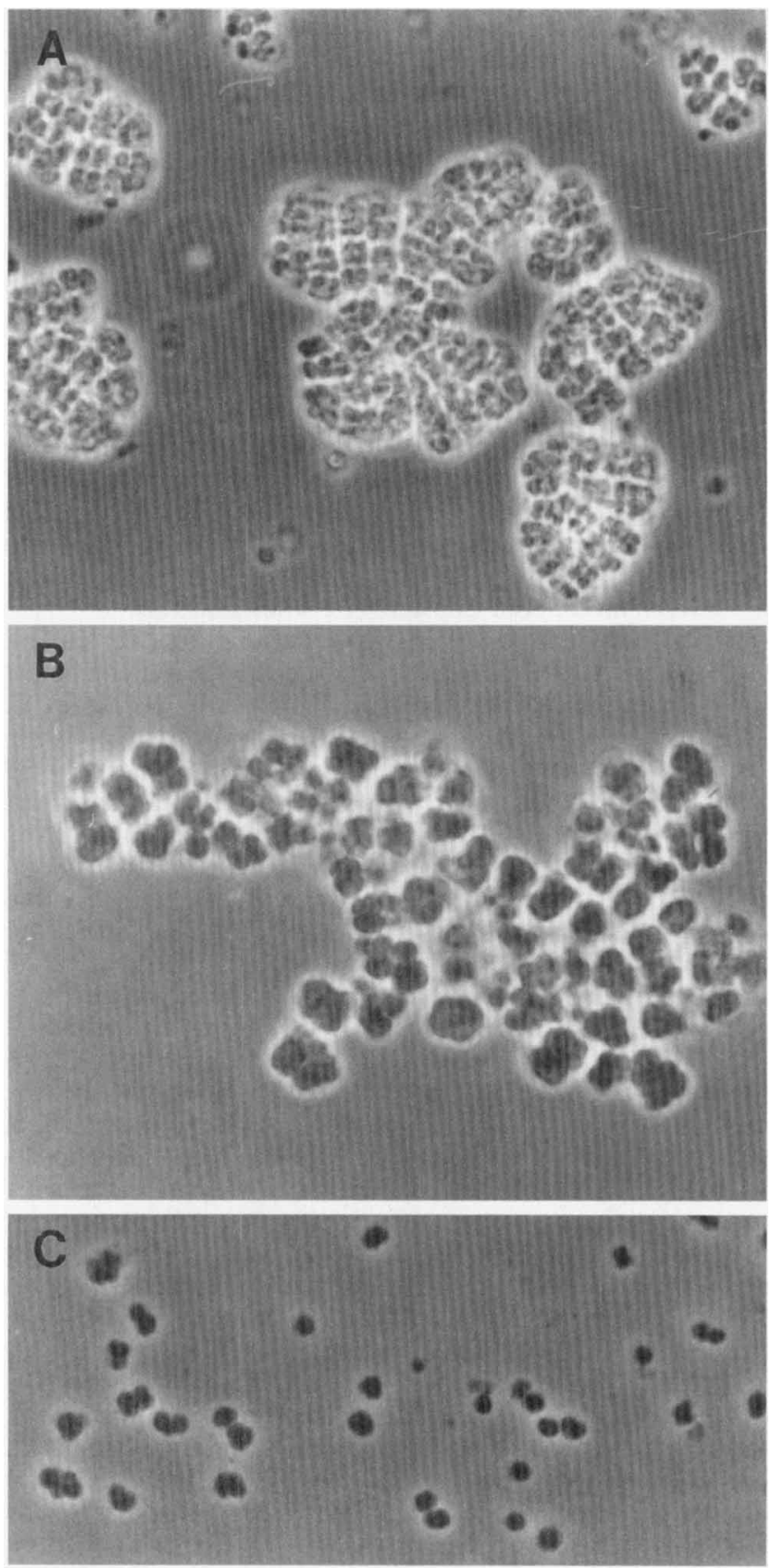

FIG. 1. Phase-contrast photomicrographs of strain AA-1042 ${ }^{\mathrm{T}}$. (A) Clusters grown on PYGV broth for 4 weeks at $20^{\circ} \mathrm{C}$. Magnification, $\times 1,280$. (B) Cluster grown on $R$ medium for 5 days at $22^{\circ} \mathrm{C}$. Magnification, $\times 1,500$. (C) Single cells, partly dividing. Magnification, $\times 1,500$.

the type strains of related taxa were determined under standardized conditions (Table 1). The peptidoglycan of strain AA- $1042^{\mathrm{T}}$ contains LL- $\mathrm{A}_{2} \mathrm{pm}$, and its interpeptide bridge consists of a single glycine residue. Position 1 of the peptide subunit is occupied by glycine. The molar ratio of the peptidoglycan amino acids Gly, Ala, Glu, and $\mathrm{LL}_{-} \mathrm{A}_{2} \mathrm{pm}$ is $2.1: 0.5$ : 1.0:1.4. On the basis of these results strain $\mathrm{AA}-1042^{\mathrm{T}}$ represents peptidoglycan type $\mathrm{A} 3 \gamma^{\prime}$ as described by Schleifer and Seidl (36). The acyl type is acetyl. Glucose and minor amounts of ribose, mannose, and rhamnose occur as cell wall sugars. The isoprenoid quinones are MK-9( $\left.\mathrm{H}_{4}\right)$ and MK-9 $\left(\mathrm{H}_{2}\right)$; the

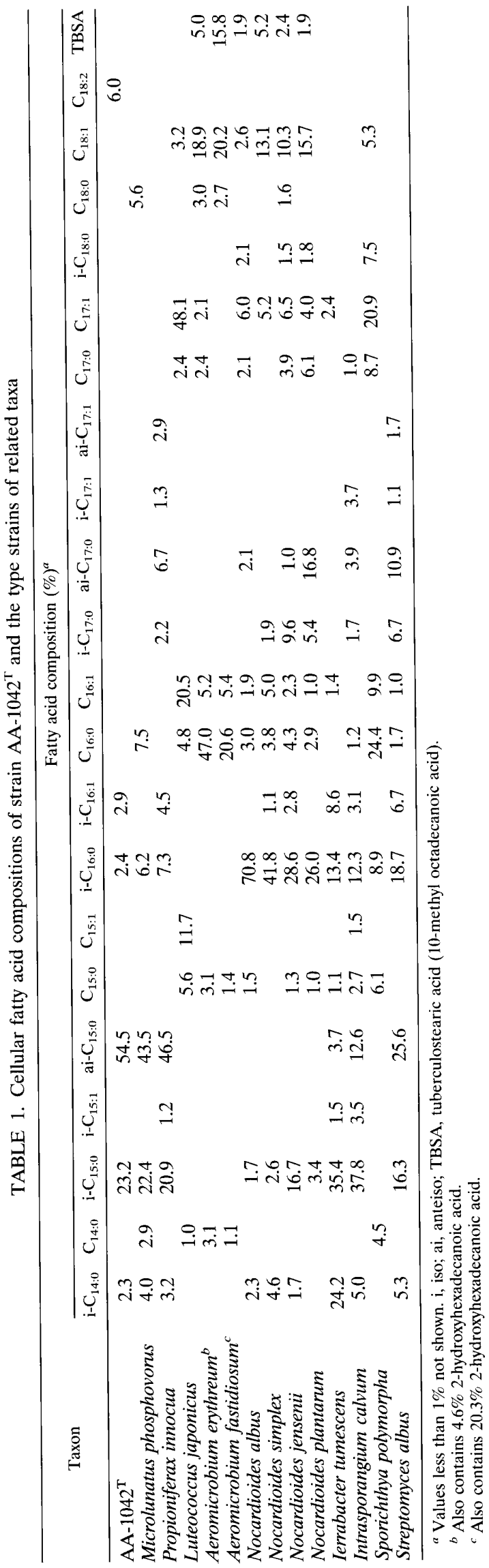


TABLE 2. Differential characteristics of strain AA- $1042^{\mathrm{T}}$ and related taxa that have $\mathrm{LL}-\mathrm{A}_{2} \mathrm{pm}$ in the cell wall ${ }^{a}$

\begin{tabular}{|c|c|c|c|c|c|c|c|c|}
\hline Taxon & $\begin{array}{c}\text { Cell } \\
\text { morphology }\end{array}$ & $\begin{array}{l}\text { Relationship } \\
\text { to oxygen }\end{array}$ & Major menaquinone(s) & $\begin{array}{l}\text { Peptidoglycan } \\
\text { interpeptide } \\
\text { bridge }\end{array}$ & $\begin{array}{l}\text { Amino acid at } \\
\text { position } 1 \text { of } \\
\text { peptide } \\
\text { subunit }\end{array}$ & Polar lipids & $\begin{array}{l}\mathrm{G}+\mathrm{C} \\
\text { content } \\
(\mathrm{mol} \%)\end{array}$ & $\begin{array}{l}\text { Refer- } \\
\text { ences(s) }\end{array}$ \\
\hline $\mathrm{AA}-1042^{\mathrm{T}}$ & $\begin{array}{l}\text { Cocci in } \\
\text { packets }\end{array}$ & $\mathrm{a}$ & MK-9 $\left(\mathrm{H}_{4}\right)$ & Gly & Gly & PI, PG, DPG, PL & 73 & \\
\hline Microlunatus & Cocci & $\mathrm{a}$ & MK-9 $\left(\mathrm{H}_{4}\right)$ & $\mathrm{Gly}^{b}$ & $\mathrm{Gly}^{b}$ & PI, PG, DPG, PL & 67.9 & 24 \\
\hline Luteococcus & Cocci & $\mathrm{f}$ & MK-9(H $\left(\mathrm{H}_{4}\right)$ & $\mathrm{Gly}^{b}$ & L-Äla ${ }^{b}$ & PI, PG, DPG, GL & $66-68$ & 42 \\
\hline Propioniferax & Rods & $\mathrm{f}$ & MK-9(H4) & Gly & L-Ala & $\mathrm{PE}, \mathrm{PG}, \mathrm{PL}, \mathrm{GL}^{b, c}$ & $59-63$ & 45,49 \\
\hline Aeromicrobium & Rods & a & MK-9 $\left(\mathbf{H}_{4}\right)$ & Gly & L-Ala & $\mathrm{PE}, \mathrm{PG}$ & $71-73$ & 21,43 \\
\hline $\begin{array}{l}\text { Propionibacterium } \\
\text { propionicus }\end{array}$ & Pleomorphic & $\mathrm{f}$ & MK-9 $\left(\mathrm{H}_{4}\right)$ & Gly & Gly & ND & $63-65$ & 34,46 \\
\hline Nocardioides albus & Hyphae & a & MK-8 $\left(\mathrm{H}_{4}\right)$ & Gly & L-Ala & PG, DPG, PL, PG-OH & $66.5-68.6$ & $5,25,28$ \\
\hline Nocardioides simplex & Rods, cocci & a & $\mathrm{MK}-8\left(\mathrm{H}_{4}\right)$ & Gly & L-Ala & PG, DPG, PL, PG-OH & 71.7 & 5,25 \\
\hline Terrabacter & Rods, cocci & $\mathrm{a}$ & MK-8( $\left(\mathrm{H}_{4}\right)$ & $\mathrm{Gly}_{3}$ & L-Ala & PE, PI, DPG, PL & $69.8-73.4$ & 5,35 \\
\hline Intrasporangium & Hyphae & a & MK-8 & $\mathrm{Gly}_{3}^{b}$ & $\mathrm{~L}-\mathrm{Ala}^{b}$ & PI, PIM, PG, DPG & 68.2 & 17 \\
\hline Sporichthya & Hyphae & $\mathrm{a}$ & MK- $9\left(\mathrm{H}_{6}\right)$, MK- $9\left(\mathrm{H}_{8}\right)$ & $\mathrm{Gly}^{b}$ & $\mathrm{~L}-\mathrm{Ala}^{b}$ & PI, PG, DPG, PL & 70.1 & 30 \\
\hline Streptomyces & Hyphae & $\mathrm{a}$ & 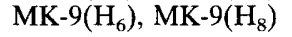 & Gly & L-Ala & PE, PI, PIM, DPG & $69-73$ & 47 \\
\hline
\end{tabular}

${ }^{a}$ Abbreviations: a, aerobic; f, facultatively anaerobic; Gly, glycine; L-Ala, L-alanine; DPG, diphosphatidylglycerol; PG, phosphatidylglycerol; PG-OH, phosphatidylglycerol containing 2-hydroxy fatty acids; PI, phosphatidylinositol; PIM, phosphatidylinositol mannosides; PE, phosphatidylethanolamine; PL, unknown phospholipid(s); GL, unknown glycolipid(s); ND, not determined. Abbreviations for menaquinones are exemplified by MK- $9\left(\mathrm{H}_{4}\right)$ : menaquinone with two of nine isoprene units hydrogenated.

${ }^{b}$ Our data supplementing previously published descriptions of the respective genera.

${ }^{c}$ Strain DSM $8251^{\mathrm{T}}$ contained five unknown glycolipids.

peak area ratio of these quinones is $63: 8$. The polar lipid pattern consists of phosphatidylglycerol, diphosphatidylglycerol, phosphatidylinositol, and one unknown phospholipid. Mycolic acids are absent. The DNA base composition is 73 $\mathrm{mol} \% \mathrm{G}+\mathrm{C}$.

Since the previously published chemotaxonomic data for some of the type species listed in Table 1 were found to be incomplete, previously undetermined characteristics are given in Table 2. Moreover, nearly all of the data available for these taxa were examined and confirmed. Except for I. calvum, no significant differences were found between the data determined in this study and the data published previously. The data reported previously for the $I$. calvum fatty acid profile, structure of the interpeptide bridge, and phospholipid pattern (17) were not confirmed by our reexamination. The chemotaxonomic characteristics of strain $\mathrm{AA}-1042^{\mathrm{T}}$ and the other $\mathrm{LL}-\mathrm{A}_{2} \mathrm{pm}$-containing actinomycete genera are summarized in Table 2.

16S rDNA sequence analysis. Nine almost complete $16 \mathrm{~S}$ rDNA sequences comprising between 1,460 and 1,484 nucleotides ( $>95 \%$ of the Escherichia coli sequence [1]) were determined in this study. New sequences were determined for a number of reference strains (see above) due to numerous ambiguities in the sequences previously deposited in the public databases. The phylogenetic dendrogram shown in Fig. 2 was reconstructed from evolutionary distances by the neighborjoining method (33). A total of 1,136 nucleotides present in all of the strains between position 39 and position 1313 (E. coli positions [1]) were used for this analysis. The phylogenetic dendrogram (Fig. 2) shows that strain AA-1042 $2^{\mathrm{T}}$ falls within the radiation of the cluster comprising the genera Microlunatus, Luteococcus, Propioniferax, and Propionibacterium. This cluster is recovered in $94 \%$ of bootstrap analyses. Strain AA$1042^{\mathrm{T}}$ represents a distinct lineage and exhibits levels of $16 \mathrm{~S}$ rDNA sequence similarity to the other members of the cluster ranging from 89.1 to $93.9 \%$. The branch point of strain AA$1042^{\mathrm{T}}$ and its closest relative, Microlunatus phosphovorus, was supported by $99 \%$ recovery in the bootstrap analysis. A comparison of the sequences of strain AA- $1042^{\mathrm{P}}$ and Microlunatus phosphovorus at 1,457 unambiguous nucleotide positions

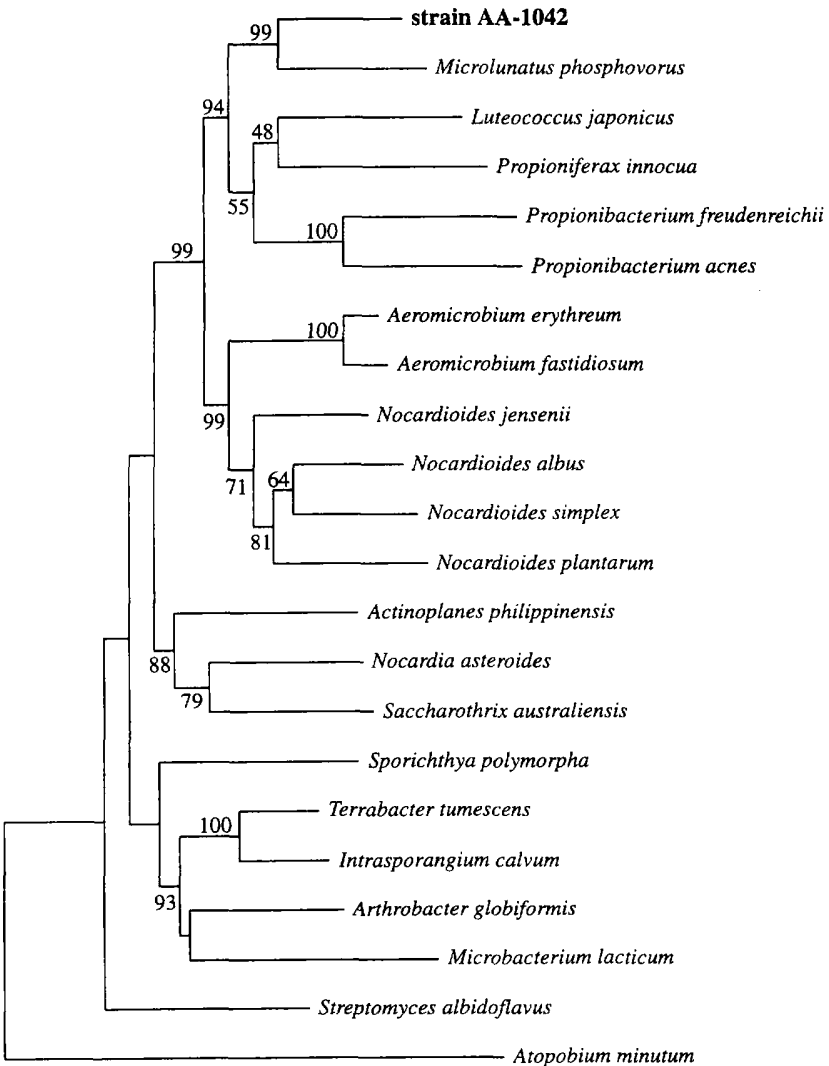

FIG. 2. 16S rDNA sequence-based phylogenetic dendrogram reconstructed from evolutionary distances by using the neighbor-joining method (33). Scale bar $=5$ inferred nucleotide substitutions per 100 nucleotides. The numbers at the branch points are bootstrap values. 
showed that these organisms exhibited $94.0 \%$ similarity. The phylogenetic position of I. calvum DSM $43043^{\mathrm{T}}$ was also determined in this study. This species clusters with $T$. tumescens (96\% sequence similarity) (Fig. 2) and Sanguibacter species (data not shown).

\section{DISCUSSION}

Our phylogenetic analysis identified the antarctic bacterial isolate AA- $1042^{\mathrm{T}}$ as a neighbor taxon of Microlunatus phosphovorus. The genomic relatedness of these taxa is also expressed at the epigenetic level, as demonstrated by very similar chemotaxonomic properties. The isoprenoid quinone composition, polar lipids, and amino acids of the peptide subunit of group A peptidoglycan (35) are identical in these two taxa. The chemotaxonomic properties clearly distinguish this pair of organisms from the other actinomycete genera containing LL$\mathrm{A}_{2} \mathrm{pm}$ in the peptidoglycan and glycine in the interpeptide bridge. Strain AA- $1042^{\mathrm{T}}$ and Microlunatus phosphovorus are both characterized by the occurrence of glycine at position 1 of the peptide subunit. This property has also been found in Propionibacterium propionicum (46), but this organism is biochemically, morphologically, and phylogenetically a true member of the genus Propionibacterium $(2,3)$. The occurrence of glycine at this position has also been found in members of the family Microbacteriaceae; however, these organisms are characterized by the rare group B peptidoglycan (35). In contrast to the previously published data for Propioniferax innocua (49), L-alanine and not glycine occupies position 1 in the peptide subunit (45). Despite striking similarities between strain AA$1042^{\mathrm{T}}$ and Microlunatus phosphovorus $\mathrm{JCM} 9379^{\mathrm{T}}$ in several chemotaxonomic properties, differences occur in the primary structure of the 16S rDNA, in morphology, in physiological properties, in the base composition of DNA, and in fatty acid composition. Generally, cells of strain AA- $1042^{\mathrm{T}}$ do not separate from each other after cell division, but packets develop and these packets aggregate to form irregular clusters. In contrast, cells of Microlunatus phosphovorus occur singly, in pairs, or in some cases in clusters (24). In submerged cultures $\mathrm{Mi}$ crolunatus phosphovorus grows well, while strain AA-1042 grows very slowly and poorly. Strain AA- $1042^{\mathrm{T}}$ is oxidase negative and uses a very narrow range of organic compounds as carbon sources, while Microlunatus phosphovorus is oxidase positive and metabolizes a wide range of organic compounds. Strain AA- $1042^{\mathrm{T}}$ does not tolerate $4 \%$ (wt/vol) $\mathrm{NaCl}$ in the growth medium, while Microlunatus phosphovorus grows in the presence of $6 \%(\mathrm{wt} / \mathrm{vol}) \mathrm{NaCl}$. Strain AA-1042 ${ }^{\mathrm{T}}$ does not reduce nitrate to nitrite, whereas Microlunatus phosphovorus does. Saturated straight-chain fatty acids with 14,16 , and 18 carbon atoms are found in Microlunatus phosphovorus but have not been found in strain AA-1042 . The fatty acid profile of strain AA-1042 ${ }^{\mathrm{T}}$ contains $6 \%$ octadecadienoic acid, a compound not found in the other LL- $\mathrm{A}_{2} \mathrm{pm}$-containing organisms included in this study.

On the basis of these differences we concluded that strain $\mathrm{AA}-1042^{\mathrm{T}}$ should not be considered a new species of the genus Microlunatus. Consequently, a new genus and species, Friedmanniella antarctica gen. nov., sp. nov., is proposed, and a description of this taxon is given below.

Description of Friedmanniella gen. nov. Friedmanniella (Fried. man.ni.el'la. M. L. dim. ending -ella; M. L. fem. n. Friedmanniella, named after E. Imre Friedmann, an American microbiologist, in recognition of his contributions to antarctic microbiology). Spherical to ellipsoidal cells that occur mostly in more or less regular packets which develop through cell division in three perpendicular planes. The packets aggregate, forming clusters. Gram positive. Nonmotile. No spores are formed. Not acid fast. Strictly aerobic. Oxidase negative. Catalase positive. Chemoorganotrophic. Only a few carbohydrates, organic acids, and other carbon sources are metabolized.

The LL- $\mathrm{A}_{2} \mathrm{pm}$-containing group $\mathrm{A} 3 \gamma^{\prime}$ peptidoglycan contains glycine in position 1 of the peptide subunit and a single glycine residue as an interpeptide bridge. The major menaquinone is MK- $9\left(\mathrm{H}_{4}\right)$, and the main fatty acids are $12-$ and 13-methyltetradecanoic acids (anteiso- $\mathrm{C}_{15: 0}$ and iso- $\mathrm{C}_{15: 0}$ ). Mycolic acids are absent. The phospholipid pattern includes phosphatidylglycerol, diphosphatidylglycerol, phosphatidylinositol, and one unknown phospholipid. The DNA base composition is 73 $\mathrm{mol} \% \mathrm{G}+\mathrm{C}$.

The type species is Friedmanniella antarctica.

Description of Friedmanniella antarctica sp. nov. Friedmanniella antarctica (ant 'arc.ti.ca. M. L. fem. adj. antarctica, isolated from Antarctica). The spherical cells are 0.5 to $2.2 \mu \mathrm{m}$ in diameter. The cells are arranged in more or less regular packets, which adhere to one another to form clusters. Growth in submerged standing and shaking cultures is slow and poor. Colonies on $\mathrm{R}$ agar are up to $2 \mathrm{~mm}$ in diameter and raised and have irregular edges and shapes. The colony surface is crumbly and dull to smooth and shiny depending on the growth medium. The orange color of colonies may become more intense when the organism is cultured in diffuse daylight. The optimum growth temperature is $22^{\circ} \mathrm{C}$. The temperature range is approximately 9 to $25^{\circ} \mathrm{C}$; no growth occurs at 6 and $28^{\circ} \mathrm{C}$. The optimal $\mathrm{pH}$ range for growth is 6.0 to 7.2 .

Catalase positive. Oxidase negative. Urease positive. Does not reduce nitrate to nitrite. Acid is produced from D-ribose, is produced weakly from L-arabinose, and is produced very weakly from D-xylose. No acid is produced from L-rhamnose, D-glucose, D-fructose, D-mannose, D-galactose, maltose, lactose, sucrose, D-cellobiose, trehalose, D-raffinose, glycerol, Dmannitol, and myo-inositol. Starch and esculin are hydrolyzed, and Tween 80 and DNA are only weakly hydrolyzed. Casein and gelatin are not hydrolyzed. Sodium formate is utilized as a carbon source. Sodium acetate, sodium aconitate, sodium benzoate, sodium citrate, disodium succinate, and potassium hydrogentartrate are not utilized. Hypoxanthine, xanthine, adenine, DL-tyrosine, and sodium hippurate are not decomposed. $\mathrm{H}_{2} \mathrm{~S}$ is produced. The DNA base composition is $73 \mathrm{~mol} \% \mathrm{G}+$ C.

The organism was isolated from a cryptoendolithic microbial community in sandstone on Linnaeus Terrace, McMurdo Dry Valleys, Antarctica.

The type strain is strain AA-1042. It has been deposited in the DSMZ-Deutsche Sammlung von Mikroorganismen und Zellkulturen $\mathrm{GmbH}$ as strain DSM $11053^{\mathrm{T}}$.

\section{ACKNOWLEDGMENTS}

We are grateful to Eva Woitzik, Carmen Schult, and Bärbel Hoffmann for excellent technical assistance.

P.H. was supported by Deutsche Forschungsgemeinschaft grants $\mathrm{Hi}$ 68/13-1 to $\mathrm{Hi}$ 68/13-4. E. I. Friedmann supported P.H. and three expeditions to the McMurdo Dry Valleys with grant DPP83-14180 from the U.S. National Science Foundation.

\section{REFERENCES}

1. Brosius, J., M. L. Palmer, P. J. Kennedy, and H. F. Noller. 1978. Complete nucleotide sequence of the 16S ribosomal RNA gene from Escherichia coli. Proc. Natl. Acad. Sci. USA 75:4801-4805.

2. Charfreitag, O., and E. Stackebrandt. 1989. Intra- and intergeneric relationships of the genus Propionibacterium. J. Gen. Microbiol. 135:2065-2070.

3. Charfreitag, O., M. D. Collins, and E. Stackebrandt. 1988. Reclassification of Arachnia propionica as Propionibacterium propionicus comb. nov. Int. J. Syst. Bacteriol. 38:354-357.

4. Collins, M. D., S. Cockcroft, and S. Wallbanks. 1994. Phylogenetic analysis 
of a new LL-diaminopimelic acid-containing coryneform bacterium from herbage, Nocardioides plantarum sp. nov. Int. J. Syst. Bacteriol. 44:523-526.

5. Collins, M. D., M. Dorsch, and E. Stackebrandt. 1989. Transfer of Pimelobacter tumescens to Terrabacter gen. nov. as Terrabacter tumescen comb. nov. and of Pimelobacter jensenii to Nocardioides as Nocardioides jensenii comb. nov. Int. J. Syst. Bacteriol. 39:1-6.

6. Collins, M. D., and D. Jones. 1980. Lipids in the classification and identification of coryneform bacteria containing peptidoglycans based on 2,4-diaminobutyric acid. J. Appl. Bacteriol. 48:459-470.

7. Collins, M. D., T. Pirouz, M. Goodfellow, and D. E. Minnikin. 1977. Distribution of menaquinones in actinomycetes and corynebacteria. J. Gen. Microbiol. 100:221-230.

8. Collins, M. D., and E. Stackebrandt. 1989. Molecular taxonomic studies on some LL-diaminopimelic acid-containing coryneforms from herbage: description of Nocardioides fastidiosa sp. nov. FEMS Microbiol. Lett. 57:289-294.

9. Cowan, S. T., and K. J. Steel. 1965. Manual for the identification of medical bacteria, p. 117 and 158. University Press, Cambridge, United Kingdom.

10. Felsenstein, J. 1985. Confidence limits on phylogenies: an approach using the bootstrap. Evolution 39:783-789.

11. Felsenstein, J. 1993. PHYLIP (phylogenetic inference package) version 3.5.1. Department of Genetics, University of Washington, Seattle.

12. Gordon, R. E., D. A. Barnett, J. E. Handerhan, and C. H.-N. Pang. 1974 Nocardia coeliaca, Nocardia autotrophica, and the nocardin strain. Int. J. Syst. Bacteriol. 24:54-63.

13. Gordon, R. E., and J. M. Mihm. 1957. A comparative study of some strains received as nocardiae. J. Bacteriol. 73:15-27.

14. Groth, I., P. Schumann, N. Weiss, K. Martin, and F. A. Rainey. 1996 Agrococcus jenensis gen. nov., sp. nov., a new genus of actinomycetes with diaminobutyric acid in the cell wall. Int. J. Syst. Bacteriol. 46:234-239.

15. Hirsch, P., B. Hoffmann, C. A. Gallikowski, U. Mews, J. Siebert, and M. Sittig. 1988. Diversity and identification of heterotrophs from antarctic rocks of the McMurdo Dry Valleys (Ross Desert). Polarforschung 58:261-269.

16. Jukes, T. H., and C. R. Cantor. 1969. Evolution of protein molecules, p. 21-132. In H. N. Munro (ed.), Mammalian protein metabolism. Academic Press, New York, N.Y.

17. Kalakoutskii, L. V. 1989. Genus Intrasporangium Kalakoutskii, Kirillova and Krasil'nikov 1967, 79 $\mathrm{AL}$, p. 2395-2397. In S. T. Williams, M. E. Sharpe, and J. G. Holt (ed.), Bergey's manual of systematic bacteriology, vol. 4. The Williams and Wilkins Co., Baltimore, Md.

18. Lányi, B. 1987. Classical and rapid identification methods for medically important bacteria. Methods Microbiol. 19:1-67.

19. MacKenzie, S. L. 1987. Gas chromatographic analysis of amino acids as the $\mathrm{N}$-heptafluorobutyryl isobutyl esters. J. Assoc. Off. Anal. Chem. 70:151-160.

20. Maidak, B. L., N. Larsen, M. J. McCaughey, R. Overbeek, G. J. Olsen, K. Fogel, J. Blandy, and C. R. Woese. 1994. The Ribosomal Database Project. Nucleic Acids Res. 22:3485-3487.

21. Miller, E. S., C. R. Woese, and S. Brenner. 1991. Description of the erythromycin-producing bacterium Arthrobacter sp. strain NRRL B-3381 as Aeromicrobium enthreum gen. nov., sp. nov. Int. J. Syst. Bacteriol. 41:363368.

22. Minnikin, D. E., L. Alshamaony, and M. Goodfellow. 1975. Differentiation of Mycobacterium, Nocardia, and related taxa by thin-layer chromatographic analysis of whole-organism methanolysates. J. Gen. Microbiol. 88:200-204.

23. Minnikin, D. E., M. D. Collins, and M. Goodfellow. 1979. Fatty acid and polar lipid composition in the classification of Cellulomonas, Oerskovia and related taxa. J. Appl. Bacteriol. 47:87-95.

24. Nakamura, K., A. Hiraishi, Y. Yoshimi, M. Kawaharasaki, K. Masuda, and Y. Kamagata. 1995. Microlunatus phosphovorus gen. nov., sp. nov., a new gram-positive polyphosphate-accumulating bacterium isolated from activated sludge. Int. J. Syst. Bacteriol. 45:17-22.

25. O'Donnell, A. G., M. Goodfellow, and D. E. Minnikin. 1982. Lipids in the classification of Nocardioides: reclassification of Arthrobacter simplex (Jensen) Lochhead in the genus Nocardioides (Prauser) emend. O'Donnell et al. as Nocardioides simplex comb. nov. Arch. Microbiol. 133:323-329.

26. Prauser, H. 1965. Aptness and application of colour codes for exact description of colours of streptomycetes. Z. Allg. Mikrobiol. 4:95-98.

27. Prauser, H. 1976. Nocardioides, a new genus of the order Actinomycetales. Int. J. Syst. Bacteriol. 26:58-65.
28. Prauser, H. 1986. Genus Nocardioides Prauser 1976, 61 AL, p. 1481-1485. In P. H. A. Sneath, N. S. Mair, M. E. Sharpe, and J. G. Holt (ed.), Bergey's manual of systematic bacteriology, vol. 2. The Williams and Wilkins Co., Baltimore, Md.

29. Prauser, H., and R. Falta. 1968. Phagensensibilität, Zellwand-Zusammensetzung und Taxonomie von Actinomyceten. Z. Allg. Mikrobiol. 8:39-46.

30. Rainey, F. A., P. Schumann, H. Prauser, R. Toalster, and E. Stackebrandt. 1993. Sporichthya polymorpha represents a novel line of descent within the order Actinomycetales. FEMS Microbiol. Lett. 109:263-268.

31. Rainey, F. A., N. Ward-Rainey, R. M. Kroppenstedt, and E. Stackebrandt. 1996. The genus Nocardiopsis represents a phylogenetically coherent taxon and a distinct actinomycete lineage: proposal of Nocardiopsaceae fam. nov. Int. J. Syst. Bacteriol. 46:1088-1092.

32. Saddler, G. S., P. Tavecchia, S. Lociuro, M. Zanol, L. Colombo, and E. Selva. 1991. Analysis of madurose and other actinomycete whole cell sugars by gas chromatography. J. Microbiol. Methods 14:185-191.

33. Saitou, N., and M. Nei. 1987. The neighbor-joining method: a new method for reconstructing phylogenetic trees. Mol. Biol. Evol. 4:406-425.

34. Schaal, K. P. 1986. Genus Arachnia Pine and Georg $1969,269^{\mathrm{AL}}$, p. 1332 1342. In P. H. A. Sneath, N. S. Mair, M. E. Sharpe, and J. G. Holt (ed.), Bergey's manual of systematic bacteriology, vol. 2. The Williams and Wilkins Co., Baltimore, Md.

35. Schleifer, K. H., and O. Kandler. 1972. Peptidoglycan types of bacterial cell walls and their taxonomic implications. Bacteriol. Rev. 36:407-477.

36. Schleifer, K. H., and P. H. Seidl. 1985. Chemical composition and structure of murein, p. 201-219. In M. Goodfellow and D. E. Minnikin (ed.), Chemical methods in bacterial systematics. Academic Press, London, United Kingdom.

37. Shirling, E. B., and D. Gottlieb. 1966. Methods for characterization of Streptomyces species. Int. J. Syst. Bacteriol. 16:313-340.

38. Smibert, R. M., and N. R. Krieg. 1981. General characterization, p. 409. In P. Gerhardt, R. G. E. Murray, R. N. Costilow, E. W. Nester, W. A. Wood, N. R. Krieg, and G. B. Phillips (ed.), Manual of methods for general bacteriology. American Society for Microbiology. Washington, D.C.

39. Stackebrandt, E., D. Witt, C. Kemmerling, R. Kroppenstedt, and W. Liesack 1991. Designation of streptomycete 16S and 23S rRNA-based target regions for oligonucleotide probes. Appl. Environ. Microbiol. 57:1468-1477.

40. Stackebrandt, E., C. Koch, O. Gvozdiak, and P. Schumann. 1995. Taxonomic dissection of the genus Micrococcus: Kocuria gen. nov., Nesterenkonia gen. nov., Kytococcus gen. nov., Dermacoccus gen. nov., and Micrococcus Cohn 1872 gen. emend. Int. J. Syst. Bacteriol. 45:682-692.

41. Staley, J. T. 1968. Prosthecomicrobium and Ancalomicrobium: new prosthecate freshwater bacteria. J. Bacteriol. 95:1921-1942.

42. Tamura, T., M. Takeuchi, and A. Yokota. 1994. Luteococcus japonicus gen nov., a new gram-positive coccus with LL-diaminopimelic acid in the cell wall. Int. J. Syst. Bacteriol. 44:348-356.

43. Tamura, T., and A. Yokota. 1994. Transfer of Nocardioides fastidiosa Collin and Stackebrandt 1989 to the genus Aeromicrobium as Aeromicrobium fas tidiosum comb. nov. Int. J. Syst. Bacteriol. 44:608-611.

44. Uchida, K., and K. Aida. 1984. An improved method for the glycolate test for simple identification of the acyl type of bacterial cell walls. J. Gen. Appl. Microbiol. 30:131-134.

45. Weiss, N. Personal communication.

46. Weiss, N., K. H. Schleifer, and O. Kandler. 1981. The peptidoglycan types of gram positive anaerobic bacteria and their taxonomic implications. Rev. Inst. Pasteur Lyon 14:3-12.

47. Williams, S. T., M. Goodfellow, and G. Alderson. 1989. Genus Streptomyces Waksman and Henrici $1943,339^{\mathrm{AL}}$, p. 2452-2492. In S. T. Williams, M. E. Sharpe, and J. G. Holt (ed.), Bergey's manual of systematic bacteriology, vol. 4. The Williams and Wilkins Co., Baltimore, Md.

48. Yamada, K., and K. Komagata. 1972. Taxonomic studies on coryneform bacteria. IV. Morphological, cultural, biochemical, and physiological characteristics. J. Gen. Appl. Microbiol. 18:399-416.

49. Yokota, A., T. Tamura, M. Takeuchi, N. Weiss, and E. Stackebrandt. 1994 Transfer of Propionibacterium innocuum Pitcher and Collins 1991 to Propioniferax gen. nov. as Propioniferax innocua comb. nov. Int. J. Syst. Bacteriol. 44:579-582. 